\title{
Pengaruh Penerapan E-Filling Pada Kepatuhan WPOP Pegawai Negeri Sipil Dengan Pemahaman Internet Sebagai Variabel Pemoderasi
}

\author{
I Gusti Ngurah Agung Putra Agniveda ${ }^{1}$ \\ Ni Luh Supadmi ${ }^{2}$ \\ ${ }^{1,2}$ Fakultas Ekonomi dan Bisnis Universitas Udayana (Unud), Bali, Indonesia \\ e-mail: putraagniveda888@gmail.com
}

\begin{abstract}
ABSTRAK
Penelitian ini bertujuan untuk mengetahui pengaruh penerapan e-filling pada kepatuhan WPOP pegawai negeri sipil dengan pemahaman internet sebagai variabel pemoderasi di KPP Pratama Denpasar Timur. Jumlah sampel yang digunakan dalam penelitian ini adalah sebanyak 100 responden dari 16.732 populasi WPOP pegawai negeri sipil efektif di KPP Pratama Denpasar Timur. Metode penentuan sampel yang digunakan adalah non-probability sampling dengan teknik purposive sampling. Pengumpulan data dalam penelitian ini dilakukan dengan metode kuesioner. Teknik analisis data yang digunakan adalah analisis Moderated Regression Analysis (MRA). Hasil penelitian menunjukkan bahwa penerapan $e$ filling berpengaruh positif terhadap kepatuhan WPOP pegawai negeri sipil dan pemahaman internet tidak mampu memoderasi pengaruh penerapan e-filling pada kepatuhan WPOP pegawai negeri sipil di KPP Pratama Denpasar Timur.
\end{abstract}

Kata kunci: E-filling, pemahaman internet, kepatuhan wajib pajak.

\begin{abstract}
This study aims to determine the effect of the application of e-filling on the compliance of the civil servant taxpayers with an understanding of the internet as a moderating variable in the East Denpasar Primary Tax Office. The number of samples used in this study were 100 respondents out of 16,732 effective civil servant populations in East Denpasar Primary Tax Office. The method of determining the sample used was non-probability sampling with a purposive sampling technique. Data collection in this study was conducted by questionnaire method. The data analysis technique used is the analysis of Moderated Regression Analysis (MRA). The results showed that the application of e-filling had a positive effect on the compliance of the civil servant taxpayers and understanding the internet was not able to moderate the effect of implementing e-filling on the compliance of the civil servant taxpayers at East Denpasar Primary Tax Office.

Keywords: E-filling, understanding of the internet, taxpayers compliance.
\end{abstract}

\section{PENDAHULUAN}

Pembangunan nasional adalah pembangunan yang dilakukan secara berkesinambungan dan terus menerus di seluruh wilayah Indonesia yang bertujuan agar kehidupan masyarakatnya dapat merasakan pembangunan secara adil dan merata (Nurmiati, 2014). Memajukan kesejahteraan rakyat dapat 
diwujudkan apabila pemerintah menjalankan pemerintahannya dengan baik dan melaksanakan pembangunan di segala bidang dengan didukung oleh pembiayaan negara yang mamadai. Untuk mencapai tujuan tersebut, pemerintah harus memerhatikan dana atau anggaran yang ada agar proses pembangunan nasional dapat berjalan dengan baik. Sektor pajak masih sangat diandalkan pemerintah sebagai sumber penerimaan utama dalam membiayai pembangunan dan belanja negara meskipun terdapat sektor-sektor lainnya yang juga dapat berkontribusi (Santi dan Lely, 2018). Sumber penerimaan negara yang digunakan untuk membiayai pengeluaran pemerintah dan pembangunan nasional berasal dari penerimaan pajak dan penerimaan bukan pajak. Penerimaan-penerimaan negara digunakan untuk pembangunan fasilitas umum, belanja negara, pembayaran gaji pegawai.

Direktorat Jenderal Pajak selalu berupaya mengoptimalkan pelayanan untuk meningkatkan kepatuhan Wajib Pajak, sehingga diharapkan dapat meningkatkan kesadaran dan keinginan masyarakat untuk tertib sebagai Wajib Pajak. Direktorat Jenderal Pajak sebagai pengurus yang ditunjuk oleh pemerintah telah melakukan reformasi perpajakan terhadap kebijakan perpajakan dan sistem administrasi perpajakan sehingga potensi penerimaan pajak dapat dikumpulkan secara optimal (Sondakh, Jullie Jeanette, 2017). Program reformasi administrasi perpajakan perlu dirancang dan dilaksanakan secara menyeluruh dan komprehensif melalui perubahan-perubahan dalam bidang struktur organisasi, proses bisnis, dan teknologi informasi dan komunikasi, manajemen sumber daya manusia, dan pelaksanaan good governance (Sari, 2013). 
Program dan kegiatan reformasi administrasi perpajakan diwujudkan dalam penerapan modernisasi sistem administrasi perpajakan. Modernisasi sistem perpajakan dilingkungan Direktorat Jenderal Pajak (DJP) bertujuan untuk menerapkan good governance dan pelayanan prima kepada masyarakat. Reformasi pertama yaitu penerapan sistem pemungutan pajak dari official assessment system digantikan dengan self assessment system. Self assessment system adalah suatu sistem dimana Wajib Pajak diberi kepercayaan untuk menghitung dan memperhitungkan, membayar, dan melaporkan sendiri pajak terutang ke kantor pajak sesuai dengan ketentuan yang telah ditetapkan dalam peraturan yang berlaku (Sari, 2013). Pelaksanaan sistem ini sangat bergantung pada kesadaran Wajib Pajak dalam memenuhi kewajiban perpajakannya. Reformasi kedua yang dilakukan pemerintah adalah dengan memanfaatkan kemajuan teknologi informasi yang semakin berkembang untuk meningkatkan kepatuhan masyarakat dalam melaporkan pajaknya. Pemerintah menerapkan teknologi informasi dan komunikasi (TIK) untuk mengaktifkan layanan $e$ goverment yang diberikan kepada warga, karyawan, pengusaha, dan lembaga (Carter dan Belanger, 2005). Melalui Keputusan Direktur Jenderal Pajak Nomor Kep-88/PJ/2004 pada bulan Mei tahun 2004 secara resmi diluncurkan produk $e$ filling.

E-filling adalah saluran baru untuk membayar pajak melalui media elektronik seperti internet (Anees dan Kumar, 2017). E-filling merupakan layanan pengisian dan penyampaian Surat Pemberitahuan Wajib Pajak yang dilakukan secara elektronik melalui sistem online yang real time melalui internet pada 
website Direktorat Jenderal Pajak atau melalui Penyedia Jasa Aplikasi yang telah ditunjuk oleh Direktorat Jenderal Pajak. Melalui sistem e-filling para Wajib Pajak lebih mudah menunaikan kewajibannya tanpa harus mengantri di kantor-kantor pelayanan pajak sehingga dirasa lebih efektif dan efisien. Penerapan sistem $e$ filling diharapkan dapat memudahkan Wajib Pajak dalam menyampaikan SPT. Setelah menggunakan layanan elektronik ini melalui internet, publik dapat menemukan bahwa sistem e-filling mudah dan bermanfaat (Kumar, 2017).

Melalui Surat Edaran Menteri Pendayagunaan Aparatur Negara dan Reformasi Birokrasi (PANRB) Nomor 8 Tahun 2015 tentang Kewajiban Penyampaian Surat Pemberitahuan Tahunan Pajak Penghasilan Wajib Pajak Orang Pribadi Oleh Aparatur Sipil Negara/Anggota Tentara Nasional Indonesia/Kepolisian Republik Indonesia Melalui E-Filling mewajibkan kepada para Pegawai Negeri Sipil (PNS), TNI, dan Polri menyampaikan Surat Pemberitahuan Tahunan (SPT) Pajak Penghasilan (PPh) Orang pribadi menggunakan e-filling. Menurut Undang-Undang Nomor 5 Pasal 1 Tahun 2014 tentang Aparatur Sipil Negara, Aparatur Sipil Negara (ASN) adalah profesi bagi pegawai negeri sipil dan pegawai pemerintah dengan perjanjian kerja yang bekerja pada instansi pemerintah. Pegawai ASN terdiri dari Pegawai Negeri Sipil (PNS) dan pegawai pemerintah dengan perjanjian kerja yang diangkat oleh pejabat pembina kepegawaian dan diserahi tugas dalam suatu jabatan pemerintahan atau diserahi tugas negara lainnya dan digaji berdasarkan peraturan perundang-undangan. Pegawai Negeri Sipil (PNS) merupakan agen pemerintah, abdi negara yang diharapkan sepantasnya menjadi panutan rakyat, tolak ukur, 
teladan, dan contoh riil terutama dalam hal menunaikan kewajiban sebagai warga negara Indonesia, khususnya dalam bidang perpajakan, karena segala kegiatan dan pembiayaan di sektor publik sumber dananya dari APBN dan APBD yang berasal dari pajak. Besar kecilnya penerimaan dari pajak salah satunya tergantung dari kepatuhan Wajib Pajak dalam membayar pajak.

Penelitian sebelumnya mengenai kepatuhan Wajib Pajak antara lain dilakukan oleh Suherman et al., (2015) penerapan e-filling tidak berpengaruh terhadap kepatuhan Wajib Pajak dalam penyampaian SPT pada KPP Pratama Tasikmalaya. Hasil yang sama juga ditunjukkan oleh penelitian Abdurrohman et al., (2014) yang menyatakan bahwa implementasi program e-filling tidak berpengaruh pada peningkatan kepatuhan Wajib Pajak Orang Pribadi pada KPP Pratama Bojonegoro. Hasil yang berbeda ditemukan oleh Noor Fadhilah Shandy (2017) yang menunjukkan penerapan e-filling dan kesadaran Wajib Pajak berpengaruh signifikan terhadap kepatuhan formal pada dinas-dinas di Kabupaten Bantul. Hal yang sama juga ditunjukkan hasil penelitian Muhrani Putri (2018) dimana respondennya adalah pegawai negeri yang terdaftar di KPP Pratama Raba Rima yang menyatakan e-filling berpengaruh positif terhadap kepatuhan Wajib Pajak.

Penelitian ini dilakukan di KPP Pratama Denpasar Timur karena dilihat dari penerimaan pajak tahun 2015 sampai dengan 2017 mengalami fluktuasi dan tidak mencapai target yang telah ditetapkan. Target penerimaan pajak beserta realisasinya disajikan pada Tabel 1 berikut ini. 
Tabel 1.

Target dan Realisasi Penerimaan Pajak di KPP Denpasar Timur Tahun 2013-2017

\begin{tabular}{ccc}
\hline Tahun & Target Penerimaan Pajak (Miliar Rupiah) & $\begin{array}{c}\text { Realisasi Penerimaan Pajak (Miliar } \\
\text { Rupiah) }\end{array}$ \\
\hline 2015 & 735.974 .936 .999 & 670.605 .162 .941 \\
2016 & 888.528 .752 .389 & 775.034 .418 .653 \\
2017 & 840.100 .350 .000 & 773.048 .702 .000 \\
\hline
\end{tabular}

Sumber: KPP Pratama Denpasar Timur, 2018

Pegawai negeri sipil yang terdaftar di KPP Pratama Denpasar Timur masih banyak yang tidak patuh terhadap kewajiban perpajakannya hal tersebut dapat terlihat dari Tabel 2.

Tabel 2.

Rasio Penggunaan $E$-filling WPOP PNS Tahun 2015-2017

\begin{tabular}{llll}
\hline Tahun & 2015 & 2016 & 2017 \\
\hline Jumlah WPOP PNS efektif & 16.194 & 16.302 & 16.372 \\
Jumlah WPOP PNS yang menggunakan e-filling & 13.309 & 11.047 & 10.026 \\
Persentase penggunaan $e$-filling & $82 \%$ & $68 \%$ & $62 \%$ \\
\hline Sumber: KPP Pratama Denpasar Timur, 2018 & &
\end{tabular}

Berdasarkan Tabel 2, jumlah WPOP PNS dari tahun 2015 hingga 2017 selalu mengalami peningkatan. Namun peningkatan tersebut tidak sejalan dengan jumlah WPOP Pegawai Negeri Sipil (PNS) yang menggunakan e-filling dalam melaporkan pajak yang cenderung menurun.

Salah satu faktor yang menyebabkan menurunnya tingkat rasio penggunaan $e$-filling sampai akhir tahun 2017 tersebut adalah diduga rendahnya pengetahuan Wajib Pajak terhadap internet. Penggunaan $e$-filling memanfaatkan jaringan internet, maka untuk dapat menggunakan e-filling Wajib Pajak dituntut untuk dapat mengoperasikan internet. Hasil penelitian Lado dan Budiantara (2018) menunjukkan pemahaman internet tidak dapat memoderasi hubungan antara penerapan e-filling dengan kepatuhan Wajib Pajak Orang Pribadi pegawai negeri sipil. Namun hasil penelitian yang berbeda dibuktikan oleh Nurhidayah 
(2015) dan Oktaviani et al., (2018) di mana pemahaman internet sebagai variabel pemoderasi dapat memperkuat hubungan antara penerapan e-filling dengan kepatuhan Wajib Pajak. Uraian tersebut meyakinkan peneliti menggunakan variabel pemahaman internet sebagai variabel pemoderasi.

Sejak ledakan global dan adopsi internet, sejumlah uang yang tidak terhitung jumlahnya telah dihabiskan untuk e-goverment di seluruh dunia. Salah satu perubahan itu adalah $e$-filling yang dilakukan untuk meningkatkan kepatuhan Wajib Pajak (Schaupp et al., 2009). E-filling dibuat dengan tujuan perbaikan proses bisnis yaitu dengan memanfaatkan teknologi informasi. Di antara berbagai program e-government, pengenalan administrasi pajak elektronik termasuk pengarsipan pajak elektronik (e-filling) telah menjadi yang terbesar (Pippin dan Tosun, 2014) Proses e-filling dirasa lebih mudah, cepat, akurat dan aman dalam hal pelaporan pajak (Ilias et al., 2008). Selain itu, dengan adanya $e$-filing ini dapat mengurangi biaya yang ditimbulkan dari penggunaan kertas (Agustiningsih, 2016). E-filling diluncurkan pada tanggal 14 Mei 2004 sesuai dengan Keputusan Jenderal Pajak No.Kep-88/PJ/2004. E-filling merupakan bagian dari sistem administrasi perpajakan modern yang digunakan untuk menyampaikan surat pemberitahuan Wajib Pajak secara elektronik kepada Direktorat Jenderal Pajak (DJP) yang dilakukan melalui sistem online yang realtime dengan memanfaatkan jaringan komunikasi internet melalui website Direktorat Jenderal Pajak (www.pajak.go.id) atau Penyedia Jasa Aplikasi atau Application Service Provider (ASP). E-filling dapat meminimalkan biaya dan waktu karena hanya dengan menggunakan komputer yang terhubung internet, penyampaian SPT dapat 
dilakukan kapan saja yaitu selama 24 jam sehari dan 7 hari dalam seminggu (termasuk hari libur) dan dimana saja tanpa perlu datang ke kantor pajak untuk memberikannya kepada petugas pajak (Suherman et al., 2015)

Wajib Pajak yang patuh adalah Wajib Pajak yang memenuhi dan melaksanakan kewajiban perpajakan sesuai dengan ketentuan berlaku dalam hukum pajak (Tambun dan Kopong, 2017). Menurut Kurnia Rahayu (2010) mengatakan bahwa kepatuhan perpajakan dapat didefinisikan sebagai sutau keadaan di mana Wajib Pajak memenuhi semua kewajiban perpajakan dan melaksanakan hak perpajakannya. Kepatuhan adalah istilah paling netral dan inklusif yang menggambarkan kesediaan orang untuk membayar pajak (Kirchler dan Wahl, 2010). Kepatuhan dalam memenuhi kewajiban perpajakan meliputi kepatuhan formal dan kepatuhan material. Kepatuhan formal dapat diidentifikasi dari kepatuhan dalam penyampaian surat pemberitahuan. Apabila wajib pajak telah melaporkan surat pemberitahuan maka wajib pajak telah memenuhi ketentuan formal, namun isinya belum tentu memenuhi ketentuan material. Wajib pajak yang memenuhi kepatuhan material adalah wajib pajak yang mengisi dengan jujur, lengkap, dan benar surat pemberitahuan sesuai ketentuan dan menyampaikannya ke KPP sebelum batas waktu akhir. Kepatuhan perpajakan menjadi penting karena ketidakpatuhan terhadap pajak secara bersamaan akan menimbulkan upaya penghindaran pajak yang mengakibatkan berkurangnya penerimaan kas negara (Inten Yulitasari \& Bambang Suprasto, 2017). Tidak adanya peningkatan kepatuhan pajak oleh masyarakat dapat mengancam kegiatan 
pemerintah yang bertujuan untuk mensejahterakan masyarakat itu sendiri (Chau, 2009).

Aspek perpajakan pada Wajib Pajak Orang Pribadi pegawai negeri sipil ini merupakan pengenaan PPh Tahunan Wajib Pajak Orang Pribadi pegawai negeri sipil yang menerapkan kewajiban self assessment dalam hal penghitungan, pembayaran dan pelaporan $\mathrm{PPh}$ tersebut. Dalam menyelesaikan kewajiban ini, Wajib Pajak Orang Pribadi pegawai negeri sipil wajib melaporkan seluruh penghasilannya selain penghasilan dari pekerjaannya sebagai pegawai negeri sipil. Pelaporan seluruh penghasilan ini masih sering diabaikan oleh pegawai negeri sipil yang disebabkan oleh ketidak pahaman atas aturan (Fatimah et al., 2012).

Technology Acceptance Model (TAM) untuk menjelaskan bagaimana pengguna teknologi menerima dan menggunakan teknologi dalam melakukan pekerjaannya (Davis, 1989). Technology Acceptance Model (TAM) merupakan salah satu teori tentang penggunaan sistem teknologi informasi yang dianggap sangat berpengaruh dan umumnya digunakan untuk menjelaskan penerimaan individual terhadap penggunaan sistem teknologi informasi. TAM merupakan model yang paling banyak digunakan dalam memprediksi penerimaan teknologi informasi (Gefen, 2003). TAM merupakan model yang digunakan untuk memprediksi penerimaan pengguna terhadap teknologi berdasarkan dua variabel, yaitu persepsi kemanfaatan (perceived usefulness) dan persepsi kemudahan penggunaan (perceived ease of use). Persepsi kemanfaatan menjadi penentu suatu sistem dapat diterima atau tidak. Wajib pajak yang beranggapan bahwa $e$-filling akan bermanfaat bagi mereka dalam melaporkan SPT menyebabkan mereka 
tertarik menggunakannya. Semakin besar ketertarikan mereka menggunakannya, maka semakin besar juga intensitas pengguna dalam menggunakan sistem informasi tersebut. Begitu juga sebaliknya yang akan terjadi jika wajib pajak menganggap e-filling tidak bermanfaat untuknya dalam hal melaporkan SPT, maka yang akan terjadi adalah wajib pajak menjadi tidak mau menggunakan $e$ filling. Hal ini berakibat pada turunnya intensitas penggunaan e-filling oleh pengguna. Persepsi kemudahan penggunaan juga menjadi penentu suatu sistem dapat diterima atau tidak. Wajib pajak yang beranggapan bahwa e-filling itu mudah digunakan akan mendorong mereka untuk terus menggunakan sistem tersebut. Kemudahan yang diberikan oleh e-filling akan menyebabkan Wajib Pajak senan dalam menggunakannya. Begitu juga sebaliknya, jika Wajib Pajak tidak merasakan kemudahan pada $e$-filling, maka Wajib Pajak akan menjadi tidak memiliki keinginan dalam menggunakannya. Persepsi yang seperti ini akan mengurangi minat Wajib Pajak dalam menggunakan $e$-filling.

Technology Acceptance Model (TAM) merupakan salah satu teori tentang penggunaan sistem teknologi informasi yang dianggap sangat berpengaruh dan umumnya digunakan untuk menjelaskan penerimaan individual terhadap penggunaan sistem teknologi informasi. Pesatnya perkembanagan penggunaan teknologi informasi dan web diikuti oleh pemerintah yang juga menggunakan teknologi ini dalam memberikan layanan dengan tujuan untuk meningkatkan kualitas layanan dan mencapai efisiensi dalam operasi mereka (Saha et al., 2012). Memaksimalkan penerimaan dari sektor pajak, direktorat jenderal pajak (DJP) melakukan pembaharuan salah satunya modernisasi pada sistem administrasi 
perpajakan di Indonesia sehingga menjadi lebih efektif dan efisien (Syaninditha dan Ery Setiawan, 2017). Direktorat Jendral Pajak (DJP) berinovasi dengan meluncurkan produk e-filling agar dapat memudahkan masyarakat untuk melaporkan pajaknya. E-filling merupakan sistem pelaporan atau penyampaian pajak dengan Surat Pemberitahuan (SPT) secara elektronik yang dilakukan melalui sistem online yang real time. Sistem e-filling yang dapat memberikan kemudahan, kenyamanan serta dapat memberikan manfaat bagi Wajib Pajak, akan membentuk sikap positif dan membuat Wajib Pajak semakin patuh dalam melaporkan pajaknya. Sementara itu, pengarsipan pajak online memungkinkan 24 jam transmisi data sehingga pembayar pajak tidak dibatasi oleh jam kantor (Warketin et al., 2002). Selain itu, teori legitimasi dalam penelitian ini juga sangat berkaitan dengan kepatuhan Wajib Pajak.dimana Wajib Pajak harus mengikuti kebijakan yang dikeluarkan oleh pemerintah. Adanya Surat Edaran Menteri Pendayagunaan Aparatur Negara dan Reformasi Birokrasi (PANRB) Nomor 8 Tahun 2015 diharapkan semua Aparatur Sipil Negara akan patuh dalam menyampaikan Surat Pemberitahuan Tahunan (SPT) Pajak Penghasilan (PPh) Orang pribadi menggunakan $e$-filling.

Penelitian Handayani dan Tambun (2016) menunjukkan penerapan sistem e-filling tidak berpengaruh signifikan terhadap kepatuhan Wajib Pajak pada perkantoran Sunrise Garden (PT. Fonusa Agung Mulia) Jakarta Barat. Penelitian dengan hasil yang berbeda ditunjukkan oleh Agustiningsih (2016) bahwa penerapan e-filling, tingkat pemahaman perpajakan, dan kesadaran Wajib Pajak berpengaruh positif terhadap kepatuhan Wajib Pajak di KPP Pratama 
Yogyakarta. Hal sama juga diungkapkan oleh Setiawan dan Barlian (2017) yang menyatakan bahwa penerapan e-filling berpengaruh positif terhadap kepatuhan Wajib Pajak. Atas dasar argumen-argumen ilmiah yang telah dijelaskan, maka hipotesis yang dapat dirumuskan adalah sebagai berikut:

$\mathrm{H}_{1}$ : Penerapan e-filling berpengaruh positif pada kepatuhan Wajib Pajak Orang Pribadi Pegawai Negeri Sipil di KPP Pratama Denpasar Timur.

Teori atribusi merupakan teori yang menjelaskan tentang perilaku seseorang. Kemauan Wajib Pajak untuk membayar pajak sangat terkait dengan persepsi Wajib Pajak dalam membuat penilaian terhadap pajak itu sendiri. Adanya penerapan sistem e-flling diharapkan dapat memberikan penilaian terhadap persepsi kenyaman, kemudahan dan kepuasan kepada Wajib Pajak sehingga dapat meningkatkan kepatuhan Wajib Pajak. Untuk dapat menggunakan sistem $e$-filling, Wajib Pajak dituntut untuk mengerti atau paham terhadap internet yaitu mengetahui bagaimana cara mengoperasikan internet. Apabila Wajib Pajak tidak dapat mengoperasikan internet, penerapan sistem tersebut tidak berpengaruh apaapa terhadap kenyaman dan kemudahan dalam penyampaian SPT kepada kantor pajak yang diharapkan dapat meningkatkan kepatuhan Wajib Pajak.

Penelitian Lado dan Budiantara (2018) menunjukkan bahwa pemahaman internet tidak memoderasi pengaruh penerapan sistem $e$-filling terhadap kepatuhan Wajib Pajak PNS. Penelitian Nurhidayah (2015) menunjukkan terdapat pengaruh positif dalam penerapan sistem e-filling terhadap kepatuhan Wajib Pajak, dan pemahaman internet dapat memoderasi pengaruh penerapan sistem e-filling terhadap kepatuhan Wajib Pajak. Hal ini sejalan dengan penelitian Oktaviani et al., (2018) yang menunjukkan hasil pemahaman internet dapat memoderasi 
(memperkuat) pengaruh penerapan sisteme e-filling terhadap kepatuhan Wajib Pajak. Atas dasar argumen-argumen ilmiah yang telah dijelaskan, maka hipotesis yang dapat dirumuskan adalah sebagai berikut:

$\mathrm{H}_{2}$ : Pemahaman internet dapat memoderasi pengaruh penerapan e-fillingpada kepatuhan Wajib Pajak Orang Pribadi Pegawai Negeri Sipil di KPP Pratama Denpasar Timur.

\section{METODE PENELITIAN}

Penelitian ini dilakukan di KPP Pratama Denpasar Timur di Jalan Kapten Tantular Nomor 4 Renon, Denpasar. Objek penelitian ini adalah kepatuhan Wajib Pajak Orang Pribadi pegawai negeri sipil di KPP Pratama Denpasar Timur yang dipengaruhi oleh penerapan $e$-filling dengan pemahaman internet sebagai variabel pemoderasi.

Populasi dalam penelitian ini adalah seluruh Pegawai Negeri Sipil yang terdaftar di KPP Pratama Denpasar Timur yang berjumlah 16.372 Wajib Pajak.Jumlah sampel ditentukan dengan rumus Slovin berikut.

$\mathrm{n}=\frac{\mathrm{N}}{1+\mathrm{N \alpha}^{2}}$

Keterangan :

$\mathrm{N}=$ Jumlah populasi

$\mathrm{n}=$ Sampel

$\alpha^{2}=$ Persen kesalahan pengambilan sampel (10\%)

Berdasarkan data yang diperoleh dari KPP Pratama Denpasar Timur, diketahui jumlah Wajib Pajak orang pribadi pegawai negeri sipil yang terdaftar per 31 Desember 2017 sebanyak 16.372 orang. Dengan menggunakan rumus slovin, maka besarnya sampel penelitian ini adalah. 


$$
\begin{aligned}
& n=\frac{16.372}{1+16.372(0,1)^{2}} \\
& n=99,89 \\
& n=100 \text { (dibulatkan) }
\end{aligned}
$$

Teknik analisis data yang digunakan dalam penelitian ini adalah uji interaksi yang sering disebut dengan Moderated Regression Analysis (MRA). Model regresi dalam penelitian ini ditunjukkan dengan persamaan sebagai berikut:

$Y=\alpha+\beta_{1} X+\beta_{2} Z+\beta_{3} X Z+\varepsilon$

Keterangan :

$\mathrm{Y}_{\mathrm{i}}=$ Kepatuhan Wajib Pajak Orang Pribadi Pegawai Negeri Sipil

$\alpha=$ Bilangan Konstanta

$B=$ Koefisien arah persamaan penelitian

$\mathrm{X}=$ Penerapan sistem $e$-flling

$\mathrm{Z}=$ Pemahaman Internet

$\varepsilon \quad=$ Kesalahan pengganggu

\section{HASIL DAN PEMBAHASAN}

Karakteristik responden merupakan profil dari responden yang berpartisipasi dalam pengisian kuesioner pada penelitian ini. Karakteristik responden dibagi menjadi beberapa kelompok. Pertama, menurut jenis kelamin digunakan untuk mengetahui proporsi wajib pajak orang pribadi pegawai negeri sipil antara lakilaki dan perempuan. Kedua, usia digunakan untuk mengetahui rentang umur Wajib Pajak Orang Pribadi pegawai negeri sipil. Ketiga, tingkat pendidikan yang digunakan untuk mengetahui tingkat pengetahuan dan intelektualitas yang dimiliki oleh Wajib Pajak Orang Pribadi pegawai negeri sipil dalam mematuhi 
ketentuan perpajakan. Rincian profil responden disajikan pada Tabel 3 sebagai berikut.

Tabel 3.

Karakteristik Responden Penelitian

\begin{tabular}{|c|c|c|c|}
\hline No & Keterangan & Jumlah & Persentase \\
\hline \multirow[t]{4}{*}{1} & Jenis Kelamin: & & \\
\hline & a. Laki-laki & 46 & $46 \%$ \\
\hline & b. Perempuan & 54 & $54 \%$ \\
\hline & Total & 100 & $100 \%$ \\
\hline \multirow[t]{6}{*}{2} & Usia: & & \\
\hline & a. $20-30$ & 21 & $21 \%$ \\
\hline & b. $31-40$ & 26 & $26 \%$ \\
\hline & c. $41-50$ & 34 & $34 \%$ \\
\hline & d. $>50$ & 19 & $19 \%$ \\
\hline & Total & 100 & $100 \%$ \\
\hline \multirow[t]{7}{*}{3} & Tingkat Pendidikan: & & \\
\hline & a. SMA & 28 & $28 \%$ \\
\hline & b. Diploma & 10 & $10 \%$ \\
\hline & c. $\mathrm{S} 1$ & 54 & $54 \%$ \\
\hline & d. $\mathrm{S} 2$ & 8 & $8 \%$ \\
\hline & e. Lainnya & 0 & $0 \%$ \\
\hline & Total & 100 & $100 \%$ \\
\hline
\end{tabular}

Sumber: Data diolah, 2018

Berdasarkan Tabel 3, dapat dilihat bahwa responden berjenis kelamin perempuan yaitu sebanyak 54 orang dan sisanya berjenis kelamin laki-laki sebanyak 46 orang. Jenis kelamin responden dapat digunakan sebagai acuan untuk mengetahui proporsi Wajib Pajak Orang Pribadi pegawai negeri sipil antara lakilaki dan perempuan dalam memenuhi kewajiban perpajakannya..

Usia responden menggambarkan kedewasaan dan pengalaman seseorang. Pada Tabel 3 dapat dilihat bahwa yang menjadi responden dengan jumlah tertinggi berumur 41 sampai 50 tahun yaitu sebesar 34 persen, dan jumlah yang terendah yaitu 19 persen berusia diatas 50 tahun. Artinya dapat disimpulkan bahwa sebagian responden berusia matang yang mencerminkan bahwa Wajib Pajak Orang Pribadi pegawai negeri sipil memiliki pengetahuan perpajakan yang memadai. 
Tingkat pendidikan responden dapat digunakan sebagai indikator untuk mengetahui tingkat pengetahuan dan intelektualitas yang dimiliki oleh responden dalam mematuhi ketentuan perpajakan. Semakin tinggi tingkat pendidikan Wajib Pajak pegawai negeri sipil, maka kepatuhan Wajib Pajak akan semakin meningkat. Berdasarkan Tabel 3 dapat dilihat bahwa responden dengan tingkat pendidikan S1 adalah yang paling banyak yaitu 54orang (54 persen). Artinya, Wajib Pajak Orang Pribadi pegawai negeri sipil efekif yang terdaftar di KPP Denpasar Timur memiliki tingkat intelektualitas yang tinggi sehingga nantinya diharapkan tingkat kepatuhan wajib pajak juga mudah untuk ditingkatkan. Tingginya tingkat pendidikan memungkinkan seseorang untuk lebih bertanggung jawab, lebih banyak menyerap pengetahuan tentang perpajakan, serta lebih sadar akan hak dan kewajibannya sebagai wajib pajak.

Statistik deskriptif memberikan gambaran umum tentang karakteristik variabel-variabel penelitian dengan menggunakan nilai minimum, maksimum, nilai rata-rata, dan standar deviasi. Hasil pengujian statistik deskriptif disajikan pada Tabel 4 .

Tabel 4.

Hasil Analisis Statistik Deskriptif

\begin{tabular}{|c|c|c|c|c|c|}
\hline Variabel & $\mathrm{N}$ & Min & $\operatorname{Max}$ & Mean & Std.Deviation \\
\hline Penerapan E-filling (X) & 100 & 16 & 48 & 39.01 & 4.500 \\
\hline $\begin{array}{l}\text { Kepatuhan Wajib Pajak Orang } \\
\text { Pribadi Pegawai Negeri Sipil } \\
\text { (Y) }\end{array}$ & 100 & 11 & 32 & 25.54 & 3.468 \\
\hline Pemahaman Internet (Z) & 100 & 9 & 24 & 19.66 & 2.716 \\
\hline Valid N (listwise) & 100 & & & & \\
\hline
\end{tabular}

Berdasarkan Tabel 4 dapat disimpulkan bahwa jumlah pengamatan (N) penelitian ini berjumlah 100. Variabel penerapan e-filling memiliki nilai minimum sebesar 16 dan nilai maksimum sebesar 48 dengan nilai rata-rata sebesar 39,01 
yang apabila dibagi dengan 12 item pernyataan akan menghasilkan nilai sebesar 3,25. Hal ini berarti rata-rata responden memberikan skor 3 pada setiap item pernyataan variabel penerapan $e$-filling. Standar deviasi pada variabel ini sebesar 4,500 yang menunjukkan bahwa standar penyimpangan data terhadap nilai rataratanya adalah 4,500 .

Variabel kepatuhan Wajib Pajak Orang Pribadi pegawai negeri sipil memiliki nilai minimum sebesar 11 dan nilai maksimum sebesar 32 dengan nilai rata-rata sebesar 25,54 yang apabila dibagi dengan 8 item pernyataan akan menghasilkan nilai sebesar 3,19. Hal ini berarti rata-rata responden memberikan skor 3 pada setiap item pernyataan variabel pengetahuan perpajakan. Standar deviasi pada variabel ini sebesar3,468 yang menunjukkan bahwa standar penyimpangan data terhadap nilai rata-ratanya adalah 3,468.

Variabel pemahaman internet memiliki nilai minimum sebesar 9 dan nilai maksimum sebesar 24 dengan nilai rata-rata sebesar 19,66 yang apabila dibagi dengan 6 item pernyataan akan menghasilkan nilai sebesar 3,27. Hal ini berarti rata-rata responden memberikan skor 3 pada setiap item pernyataan variabel kualitas pelayanan fiskus. Standar deviasi pada variabel ini sebesar 2,716 yang menunjukkan bahwa standar penyimpangan data terhadap nilai rata-ratanya adalah 2,716 .

Uji normalitas digunakan untuk mengetahui apakah variabel residualnya memiliki distribusi normal atau tidak. Uji normalitas dalam penelitian ini menggunakan uji statistik non-parametrik One Sample Kolmogorov-Smirnov Test. Hasil uji normalitas disajikan pada Tabel 5. 
Tabel 5.

Hasil Uji Normalitas

\begin{tabular}{cc}
\hline & Unstandardized Residual \\
\hline $\mathrm{N}$ & 100 \\
Asymp.Sig. (2-tailed) & 0,180 \\
\hline
\end{tabular}

Sumber: Data diolah, 2018

Berdasarkan Tabel 5 menunjukkan bahwa unstandardized residual memiliki nilai Asymp.Sig. (2-tailed) sebesar 0,180 yang lebih besar dari taraf signifikansi 0,05. Hal ini berarti seluruh data berdistribusi normal.

Pengujian heteroskedastisitas dalam penelitian ini menggunakan uji Glejser. Tingkat probabilitas signifikansi masing-masing variabel bebas jika lebih besar dari 0,05 maka dapat disimpulkan tidak terdapat heteroskedastisitas. Hasil uji heteroskedastisitas disajikan pada Tabel 6.

Tabel 6.

Hasil Uji Heteroskedastisitas

\begin{tabular}{ccc}
\hline Variabel & Sig. & Keterangan \\
\hline Penerapan E-filling $(\mathrm{X})$ & 0,714 & Tidak Terjadi \\
& & Heteroskedastisitas \\
Pemahaman Internet (Z) & 0,839 & Tidak Terjadi \\
& & Heteroskedastisitas \\
\hline Sumber: Data diolah, 2018 & &
\end{tabular}

Berdasarkan Tabel 6 dapat dilihat hasil uji heteroskedastisitas menunjukkan bahwa nilai signifikansi masing-masing variabel diatas 0,05. Jadi, dapat disimpulkan bahwa model regresi dalam penelitian ini bebas dari gejala heteroskedastisitas.

Koefisien determinasi digunakan untuk mengukur sejauh mana kemampuan variabel independen dalam menerangkan variasi variabel dependen. Hasil uji koefisien determinasi disajikan pada Tabel 7. 
Tabel 7.

Hasil Uji Koefisien Determinasi

\begin{tabular}{ccccc}
\hline Model & $\mathrm{R}$ & $\mathrm{R}$ Square & $\begin{array}{c}\text { Adjusted R } \\
\text { Square }\end{array}$ & $\begin{array}{c}\text { Std. Error of the } \\
\text { Estimate }\end{array}$ \\
\hline 1 & $.751^{\mathrm{a}}$ & .565 & .551 & 2.324 \\
\hline
\end{tabular}

Sumber: Data diolah, 2018

Berdasarkan Tabel 7, angka adjusted $R$ square sebesar 55,1 persen menunjukkan bahwa 55,1 persen variabel kepatuhan Wajib Pajak Orang Pribadi pegawai negeri sipil yang bisa dijelaskan oleh variabel penerapan e-filling, sisanya 44,9 persen dijelaskan faktor lain.

Uji F digunakan untuk mengetahui kelayakan dari model regresi sebagai alat analisis yang menguji pengaruh variabel independen terhadap variabel dependen. Hasil uji F disajikan pada Tabel 8.

Tabel 8.

Hasil Uji F

\begin{tabular}{clccccc}
\hline Model & & Sum of & df & Mean & F & Sig. \\
& & Squares & & Square & & \\
\hline \multirow{2}{*}{1} & Regression & 672.263 & 3 & 224.088 & 41.484 & $.000^{\mathrm{a}}$ \\
& Residual & 518.577 & 96 & 5.402 & & \\
& Total & 1190.840 & 99 & & & \\
\hline
\end{tabular}

Sumber: Data diolah, 2018

Dari Tabel 8, nilai signifikansi $\mathrm{F}$ adalah sebesar 0,000 yang lebih kecil dari $\alpha=0,05$. Maka dapat disimpulkan bahwa variabel penerapan $e$-filling dan pemahaman internet mampu memprediksi atau menjelaskan kepatuhan Wajib Pajak Orang Pribadi pegawai negeri sipil di KPP Pratama Denpasar Timur.

Uji hipotesis (Uji statistik t) bertujuan untuk melihat ada tidaknya pengaruh varibael bebas (penerapan e-filling) dan variabel pemoderasi (pemahaman internet) terhadap variabel terikat (kepatuhan Wajib Pajak Orang Pribadi pegawai negeri sipil). Uji statistik $t$ menjawab hipotesis yang dikembangkan di dalam penelitian ini. Hasil uji tdisajikan pada Tabel 9. 
Tabel 9.

Hasil Uji t

\begin{tabular}{|c|c|c|c|c|c|c|}
\hline \multicolumn{2}{|c|}{ Model } & \multicolumn{2}{|c|}{$\begin{array}{l}\text { Unstandardized } \\
\text { Coefficients }\end{array}$} & \multirow{2}{*}{$\begin{array}{c}\text { Standardized } \\
\text { Coefficients } \\
\text { B }\end{array}$} & \multirow[t]{2}{*}{$\mathrm{t}$} & \multirow[t]{2}{*}{ Sig. } \\
\hline & & B & $\begin{array}{l}\text { Std. } \\
\text { Error }\end{array}$ & & & \\
\hline \multirow[t]{4}{*}{1} & (Constant) & -6.282 & 6.706 & & -.937 & .351 \\
\hline & $X$ & .664 & .185 & .861 & 3.596 & .001 \\
\hline & $\mathrm{Z}$ & .809 & .372 & .634 & 2.178 & .032 \\
\hline & $\mathrm{XZ}$ & -0.13 & .009 & -.629 & -1.370 & .174 \\
\hline
\end{tabular}

Sumber: Data diolah, 2018

Berdasarkan Tabel 9 menunjukkan t hitung penerapan e-filling adalah sebesar 3,596 dengan signifikansi t bernilai 0,001 (signifikan). Hal ini berarti penerapan $e$-filling berpengaruh positif terhadap kepatuhan Wajib Pajak Orang Pribadi pegawai negeri sipil. Variabel pemahaman internet mempunyai t hitung 2,178 dengan signifikansi 0,032 (signifikan). Variabel interaksi antara variabel penerapan $e$-filling dan pemahaman internet $\left(\mathrm{X}^{*} \mathrm{Z}\right)$ mempunyai t hitung sebesar 1,370 dengan signifikansi 0,174 (tidak signifikan).Hal ini berarti bahwa variabel pemahaman internettidak dapat memoderasi dalam hubungan antara penerapan $e$ filling dengan kepatuhan Wajib Pajak Orang Pribadi pegawai negeri sipil.

Berdasarkan hasil analisis persamaan Moderated Regression Analysis (MRA) dengan menggunakan program SPSS didapat hasil sebagai berikut:

$$
Y=-6,282+0,664 X+0,809 Z-0,13 X Z+\varepsilon
$$

Nilai konstanta sebesar $-6,282$ menunjukkan bahwa bila penerapan $e$ filling (X), pemahaman internet (Z), dan interaksi penerapan e-filling dengan pemahaman internet (XZ) sama dengan nol maka kepatuhan Wajib Pajak Orang pribadi pegawai negeri sipil akan menurun sebesar 6,282 satuan.

Nilai koefisien $\beta_{1}=0,664$ berarti menunjukkan bila penerapan e-filling $(\mathrm{X})$ bertambah 1 satuan, maka nilai dari kepatuhan Wajib Pajak Orang Pribadi 
pegawai negeri sipil (Y) akan mengalami peningkatan sebesar 0,664 satuan dengan asumsi variabel bebas lainnya konstan.

Nilai koefisien $\beta_{2}=0,809$ berarti menunjukkan bila pemahaman internet (Z) bertambah 1 satuan, maka nilai dari kepatuhan wajib pajak orang pribadi (Y) akan mengalami peningkatan sebesar 0,809 satuan dengan asumsi variabel bebas lainnya konstan.

Nilai koefisien $\beta_{3}=-0,13$ memiliki arti bahwa nila interaksi antara penerapan e-filling (X) dengan pemahaman internet $(\mathrm{Z})$ meningkat satu satuan, maka kepatuhan Wajib Pajak Orang Pribadi pegawai negeri sipil akan menurun sebesar 0.13 satuan.

Berdasarkan Tabel 9 nilai signifikansi t untuk variabel penerapan $e$-filling sebesar 0,001 yang lebih kecil dari $\alpha=0,05$. Hal ini menunjukkan hipotesis pertama dalam penelitian ini diterima yaitu, penerapan e-filling berpengaruh positif terhadap kepatuhan Wajib Pajak Orang Pribadi pegawai negeri sipil di KPP Pratama Denpasar Timur. Nilai koefisien regresi penerapan e-filling (X) sebesar 0,664 menunjukkan adanya pengaruh positif penerapan e-filling pada kepatuhan Wajib Pajak Orang Pribadi pegawai negeri sipil. Semakin baik sistem penerapan $e$-filling akan menyebabkan semakin meningkat kepatuhan Wajib Pajak Orang Pribadi pegawai negeri sipil. Wajb Pajak Orang Pribadi pegawai negeri sipil yang telah menggunakan $e$-filling merasakan manfaat dalam mempermudah pelaporan pajak, sehingga Wajib Pajak Orang Pribadi pegawai negeri sipil cenderung untuk ingin melaporkan pajak yang merupakan kewajibannya. Semakin banyak Wajib Pajak Orang Pribadi pegawai negeri sipil yang sadar 
untuk melaporkan pajak maka semakin meningkat kepatuhan Wajib Pajak Orang Pribadi pegawai negeri sipil. Tingginya tingkat kepatuhan, maka akan meningkatkan pendapatan negara di sektor pajak.

Hasil penelitian ini mengkonfirmasi teori Technology Acceptance Model yaitu kemanfaatan (usefulness) dan kemudahan penggunaan (ease to use) yang dirasakan oleh Wajib Pajak Orang Pribadi pegawai negeri sipil dalam menggunakan e-filling yang mampu meningkatkan kepatuhan sukarela Wajib Pajak.Hasil penelitian ini juga mendukung teori legitimasi dimana melaui Surat Edaran Menteri Pendayagunaan Aparatur Negara dan Reformasi Birokrasi (PANRB) Nomor 8 Tahun 2015 sangat berkontribusi dalam peningkatan kepatuhan Wajib Pajak Orang Pribadi pegawai negeri sipil dalam melaporkan pajaknya dengan menggunakan e-filling. Hasil penelitian ini konsisten dengan penelitian yang dilakukan oleh Agustiningsih (2016) dan Setiawan \& Barlian (2017) yang mengungkapkan penerapan e-filling berpengaruh positif terhadap kepatuhan Wajib Pajak.

Berdasarkan Tabel 9 nilai signifikansi t untuk interaksi variabel penerapan e-fillingdengan pemahaman internet (XZ) adalah sebesar 0,174 yang lebih besardari $\alpha=0,05$ dengan nilai koefisien regresi sebesar $-0,13$. Hal ini menunjukkan hipotesis kedua dalam penelitian ini ditolak. Hal ini memiliki arti bahwa pemahaman internet tidak mampu memoderasi pengaruh penerapan $e$ filling pada kepatuhan Wajib Pajak Orang pribadi pegawai negeri sipil di KPP Pratama Denpasar Timur. Hasil ini tidak mendukung hipotesis yang diajukan bahwa pemahaman internet dapat memperkuat hubungan antara penerapan $e$ - 
filling pada kepatuhan Wajib Pajak Orang Pribadi pegawai negeri sipil. Hal ini bisa disebabkan karena Wajib Pajak Orang Pribadipegawai negeri sipil tersebut walaupun memiliki pemahaman internet yang baik, penyampaian SPT melalui $e$ filling masih bisa dilakukan oleh siapa saja sehingga bagi Wajib Pajak Orang Pribadi pegawai negeri sipil dapat meminta bantuan orang lain (Lado dan Budiantara, 2018). Hasil penelitian ini mendukung teori atribusi dimana kemauan Wajib Pajak untuk membayar pajak sangat terkait dengan persepsi Wajib Pajak dalam membuat penilaian terhadap pajak itu sendiri.

Hasil penelitian ini tidak mendukung dengan hasil penelitian dari Nurhidayah (2015) dan Oktaviani et al., (2018) yang menyatakan pemahaman internet dapat memoderasi (memperkuat) pengaruh penerapan sistemefillingterhadap kepatuhan Wajib Pajak.Namun hasil penelitian ini konsisten dengan hasil penelitian dari Lado dan Budiantara (2018) yang mengungkapkanpemahaman internet tidak memoderasi pengaruh penerapan sistem $e$-filling terhadap kepatuhan Wajib Pajak pegawai negeri sipil.

Hasil penelitian ini memberikan tambahan informasi mengenai bagaimana penerpana $e$-filling dan pemahaman internet memengaruhi kepatuhan Wajib Pajak Orang Pribadi pegawai negeri sipil. Terdapat bukti empiris yang diperoleh melalui penelitian ini yang menunjukkan bahwa e-filling berpengaruh pada kepatuhan Wajib Pajak Orang Pribadi pegawai negeri sipil yang. Hal ini menunjukkan bahwa semakin tinggi tingkat penerapan e-filling maka semakin tinggi pula tingkat kepatuhan Wajib Pajak Orang Pribadi pegawai negeri sipil. Hal ini didukung dengan adanya teori technology acceptance model (TAM) yang 
menyebutkan bahwa kemanfaatan (usefulness) dan kemudahan penggunaan (ease to use) dirasakan oleh Wajib Pajak Orang Pribadi pegawai negeri sipil dalam menggunakan e-filling, serta teori legitimasi yang menyebutkan bahwa Wajib Pajak harus mengikuti kebijakan yang dikeluarkan oleh pemerintahyang merupakan sistem sosial yang lebih besar.

Hasil penelitian ini diharapkan dapat memberikan kontribusi positif bagi semua pihak khususnya pegawai negeri sipil yang efektif di KPP Pratama Denpasar Timur dalam meningkatkan kepatuhan perpajakannya. Peneltian ini menjelaskan penerapan e-filling memengaruhi kepatuhan Wajib Pajak Orang Pribadi pegawai negeri sipil sehingga diharapkan nantinya ada upaya-upaya berkelanjutan yang dilakukan oleh KPP Pratama Denpasar Timur untuk terus meningkatkan kepatuhan Wajib Pajak pegawai negeri sipil mengingat mereka adalah contoh riil bagi masyarakat menunaikan kewajiban sebagai warga negara Indonesia.

\section{SIMPULAN}

Penerapan e-filling berpengaruh positif pada kepatuhan Wajib Pajak Orang Pribadi pegawai negeri sipil yang terdaftar di KPP Pratama Denpasar Timur. Artinya semakin baik penerapan sistem e-filling, maka tingkat kepatuhan Wajib Pajak Orang Pribadi pegawai negeri sipil akan meningkat.

Pemahaman internet tidak dapat memoderasi pengaruh penerapan $e$-filling pada kepatuhan Wajib Pajak Orang Pribadi pegawai negeri sipil yang terdaftar di KPP Pratama Denpasar Timur. Hal ini menunjukkan bahwa paham atau tidaknya 
Wajib Pajak dengan internet tidak mempengaruhi penerapan e-filling untuk meningkatkan kepatuhan Wajib Pajak Orang Pribadi negeri sipil dalam kewajiban pelaporan pajaknya.

Dalam upaya untuk meningkatkan kepatuhan Wajib Pajak, Kantor Pelayanan Pajak Pratama Denpasar Timur harus terus meningkatkan kualitas pelayanan pajak, (dalam hal ini e-filling). Sanksi perpajakan terhadap PNS/TNI/Polri juga harus dikenakan secara tegas mengingat mereka merupakan agen pemerintah yang diharapkan sepantasnya menjadi teladan dan contoh riil terutama dalam hal menunaikan kewajiban sebagai warga negara Indonesia.

Bagi peneliti selanjutnya diharapkan dapat menggunakan lokasi dan sampel penelitian yang berbeda, menambah jumlah sampel dan mengembangkan variabel yang sudah ada dalam penelitian ini, baik menambahkan variabel pemoderasi selain pemahaman internet, serta dapat menambahkan variabel intervening seperti sosialiasasi pajak, agar hasil penelitian dapat digeneralisasi.

\section{REFERENSI}

Abdurrohman, S., Domai, T., \& Shobaruddin, M. (2014). Implementasi Program E-filling dalam Upaya Peningkatan Kepatuhan Wajib Pajak Orang Pribadi, Bojonegoro. Jurnal Administrasi Publik (JAP) Universitas Brawijaya, 3, 807-811.

Agustiningsih, W. (2016). Pengaruh Penerapan E-Filing, Tingkat Pemahaman Perpajakan Dan Kesadaran Wajib Pajak Terhadap Kepatuhan Wajib Pajak Di Kpp Pratama Yogyakarta. Jurnal Nominal, V.2.

Anees, M., \& Kumar, M. (2017). Perception Of Taxpayers' Towards E-File Adoption. International Journal of Research - Granthaalayah, 5(11).

Carter, L., \& Belanger, F. (2005). The Utilization of E-Government Services: Citizen Trust, Innovation and Acceptance Factors. Info Systems Journal 
Pamplin College of Business 15, 5-25.

Chau, L. (2009). A Critical Review of Fischer Tax Compliance Model (A Research Syntesis). Journal of Accounting and Taxation, 1(2), 34-40.

Davis, F. D. (1989). Perceived usefulness, perceived ease of use, and user acceptance of information technology. MIS Quarterly (1989), 319-340.

Fatimah, H., Nugroho, H., \& Purwaji, A. (2012). Kajian Aspek Perpajakan WP Orang Pribadi PNS Dalam Pemenuhan Kewajiban Self Assessment System (Studi Kasus: Politeknik Negeri Jakarta). Jurnal Ekonomi Dan Bisnis, 11.

Gefen, D. (2003). TAM or just plain habit: A look at experienced online shoppers." Journal of Organizational and End User Computing (JOEUC). Journal of Organizational and End User Computing (JOEUC), 15.3, 1-13.

Handayani, K. R., \& Tambun, S. (2016). Pengaruh Penerapan Sistem E-Filing Dan Pengetahuan Perpajakan Terhadap Kepatuhan Wajib Pajak Dengan Sosialisasi Sebagai Variabel Moderating (Survei pada Perkantoran Sunrise Garden di Wilayah Kedoya, Jakarta Barat). Media Akuntansi Perpajakan, 1.

Ilias, A., Suki, N. M., Yasoa, M. R., \& Rahman, R. A. (2008). A Study of Taxpayers' Intention in Using E-Filing System: A Case in Labuan F.T s. Computer and Information Science, 1.

Inten Yulitasari, A. ., \& Bambang Suprasto, H. (2017). Pengaruh Tanggung Jawab Moral, Sanksi Perpajakan Dan Penerapan Sistem E-Filing Pada Kepatuhan Pelaporan Wajib Pajak. E-Jurnal Akuntansi Universitas Udayana, 20.2, 1360-1389.

Kirchler, E., \& Wahl, I. (2010). Tax Compliance Inventory TAX-I: Designing an Inventory for Surveys of Tax Compliance. Journal of Economic Psychology, 31,331 .

Kumar, S. (2017). A Study On Income Tax Payers Perception Towards Electronic Filing. Journal of Internet Banking and Commerce, 22.

Kurnia Rahayu, S. (2010). Perpajakan Indonesia: Konsep dan Aspek Formal.

Lado, Y. O., \& Budiantara, M. (2018). Pengaruh Penerapan Sistem E-Filling Terhadap Kepatuhan Wajib Pajak Orang Pribadi Pegawai Negeri Sipil Dengan Pemahaman Internet Sebagai Variabel Pemoderasi. JRAMB, Prodi Akuntansi, Fakultas Ekonomi, UMB Yogyakarta, 4.

Muhrani Putri, M. (2018). Pengaruh E-Filing, E-Billing, dan E-Tax Terhadap Kepatuhan Wajib Pajak. Skripsi. Universitas Islan Indonesia 
Noor Fadhilah Shandy, F. (2017). Pengaruh Penerapan E-filing dan Kesadaran Wajib Pajak Terhadap Kepatuhan Formal (Studi Pada Wajib Pajak Orang Pribadi PNS pada Dinas-Dinas di Kabupaten Bantul). Skripsi. Universitas Pembangunan Nasional "Veteran" Yogyakarta

Nurhidayah, S. (2015). Pengaruh Penerapan Sistem E-filing Terhadap Kepatuhan Wajib Pajak dengan Pemahaman Internet Sebagai Variabel Pemoderasi. Skripsi. Universitas Negeri Yogyakarta

Nurmiati. (2014). Pengaruh Denda, Kesadaran Wajib Pajak, Kualitas Pelayanan Fiskus, dan Kondisi Keuangan Terhadap Kepatuhan Wajib Pajak Orang Pribadi di KPP Pratama Makassar Utara. Skripsi. Universitas Hasanuddin

Oktaviani, R. M., Sunarto, S., \& Lita, N. (2018). Pemahaman Internet Sebagai Pemoderasi Penerapan Sistem E-Filling Terhadap Kepatuhan Wajib Pajak. Prosiding SENDI_U 2018.

Pippin, S. E., \& Tosun, M. S. (2014). Electronic Tax Filing in the United States: An Analysis of Possible Success factors. Electronic Journal of EGovernment, 12(1).

Saha, P., Nath, A. K., \& Salehi-Sangari, E. (2012). Evaluation of Government ETax Websites: An Information Quality and System Quality Approach. Transforming Government: People, Process, and Policy, 6(3), 300-321.

Santi Krisna Dewi, L. P., \& Lely Aryani Merkusiwati, N. K. (2018). Pengaruh Kesadaran Wajib Pajak, Sanksi Perpajakan, E-Filing, dan Tax Amnesty Terhadap Kepatuhan Pelaporan Wajib Pajak. E-Jurnal Akuntansi Universitas Udayana, 22, 1626-1655.

Sari, D. (2013). Konsep Dasar Perpajakan.

Schaupp, L. C., Carter, L., \& Hobbs, J. (2009). E-File Adoption: A Study of U.S. Taxpayers' Intentions. Proceedings of the 42nd Hawaii International Conference on System Sciences.

Setiawan, D. R., \& Barlian, A. (2017). Pengaruh Penerapan Sistem E-Filing Dan Kesadaran Wajib Pajak Terhadap Kepatuhan Wajib Pajak Orang Pribadi Pada Kpp Pratama Jakarta Gambir Tiga. Skripsi. Institut Ilmu Sosial dan Manajemen STIAMI

Sondakh Jullie Jeanette. (2017). Behavioral Intention to Use E-Tax Service System: An Application of Technology Acceptance Model. European Research Studies, XX(2A), 48-64.

Suherman, M., Almunawwaroh, M., \& Marliana, R. (2015). Pengaruh Penerapan 
E-Filing Terhadap Kepatuhan Wajib Pajak Dalam Penyampaian Surat Pemberitahuan (SPT) TahunanPada Kantor Pelayanan Pajak Pratama Kota Tasikmalaya. Media Riset Akuntansi, Auditing \& Informasi Universitas Siliwangi, 15.

Syaninditha, S. A. P., \& Ery Setiawan, P. (2017). Pengaruh Persepsi Kegunaan, Persepsi Kemudahan, Faktor Sosial, Dan Kondisi Yang Memfasilitasi Terhadap Minat Penggunaan E-Filing. E-Jurnal Akuntansi Universitas Udayana, 21.1, 86-115.

Tambun, S., \& Kopong, Y. (2017). The Effect Of E-Filing On The Of Compliance Individual Taxpayer, Moderated By Taxation Socialization. South East Asia Journal of Contemporary Business, Economics and Law, 13(1).

Warketin, M., Gefen, D., Pavlou, P. A., \& Rose, G. M. (2002). Encouraging Citizen Adoption of E-Government by Building Trust. Electronic Markets, $12,157-162$. 